\title{
Audit Partner Quality and Audit Report Timeliness in Oman: A Conceptual Framework
}

\author{
Nahla Abdulrahman Mohammed Raweh (Corresponding author) \\ Tunku Puteri Intan Safinaz School of Accountancy, College of Business \\ Universiti Utara Malaysia, 06010 UUM Sintok, Kedah, Malaysia \\ E-mail: nahlaraweh@gmail.com \\ Hasnah Kamardin \\ Tunku Puteri Intan Safinaz School of Accountancy, College of Business \\ Universiti Utara Malaysia, 06010 UUM Sintok, Kedah, Malaysia \\ E-mail: hasnahk@uum.edu.my \\ Mazrah Malik@Malek \\ Tunku Puteri Intan Safinaz School of Accountancy, College of Business \\ Universiti Utara Malaysia, 06010 UUM Sintok, Kedah, Malaysia \\ E-mail: mazrah@uum.edu.my
}

Received: March 10, 2019

Accepted: March 23, 2019 Published: March 27, 2019

doi:10.5296/ijafr.v9i1.14478

URL: https://doi.org/10.5296/ijafr.v9i1.14478

\begin{abstract}
In response to recent call on the need for audit scholars to utilize a richer set of audit firm characteristics, auditor office, and the individual partner characteristics to capture audit competency, this study aims to expand the scope of relevant research by conceptually examining the association between audit partner quality by three characteristics namely, education, experience and tenure, and audit report timeliness in the emerging market, based on previous literature. This study adds to the growing research by providing the conceptual model showing the importance of audit partner characteristics (e.g. education, experience and
\end{abstract}


tenure) affecting the quality of audit outputs such as audit report timeliness, and agency theory is predicted to explain this effect on the audit report timeliness.

Keywords: Audit partner quality, Audit report timeliness, Oman

\section{Introduction}

The series of financial scandals that occurred around the world have eroded confidence in the transparency and quality of financial statements, and created doubt in the mind of investors, which cause loss of trust by investors. For instance, in Oman in 1990s, failure of the largest companies such as National Rice Mills SAOG and Oman National Investment Company Holding SAOG, and a sharp decline in stock prices, losing approximately $70 \%$ of its value (Dry, 2003), called for the attention of the investors, because they deeply suffered loss of their investments. In the US, the scandals involving Enron, WorldCom and Lehman Brothers raised concerns of regulatory bodies on existing regulations, part of which was changed the deadline rule for filing annual reports from 90 days to 60 days after the end of financial year in 2005 by the United States (US) Security Exchange Commission (SEC) (Abernathy, Barnes, Stefaniak \& Weisbarth, 2017). This amendment is to emphasize the relevance of the timeliness of annual reports disclosure (Abernathy et al., 2017), and enhance the timeliness of audited financial reporting, as well as to restore the confidence of investors in the capital markets (Lee \& Jahng, 2008). Timeliness is considered as the main factor reflecting the quality and transparency of financial statements and its credibility (Ram \& Hassan, 2017). The Financial Accounting Standards Board (FASB) recognizes timeliness as a significant part of relevance, and one of the primary qualitative characteristics of accounting information usefulness and quality in the Statement of Financial Accounting Concepts No.8 (FASB, 2010).

Arguably, one of the most primary determinants for the quality and transparency of accounting information and enhancing investors' confidence in the efficiency of capital markets is timeliness (Owusu-Ansah, 2000; Oussii \& Taktak, 2018). However, as requested by securities organizers and regulations in many countries worldwide such as the SEC, firms are only allowed to release their annual financial reports after the completion of an external audit and issue the audit report (Abernathy et al., 2017). Therefore, audit timeliness is viewed as the key determinant for the timeliness of financial report filings (Owusu-Ansah, 2000; Abernathy et al., 2017). Audit report timeliness referred to the length of time between the end of company's financial year and the date of signing audit report (Habib, 2015; Swanson \& Zhang, 2018).

Prior studies indicated that, timely audit report is achieved if auditors take short time to complete legal audit process in order to help companies to file their annual reports within the deadline (Baatwah, Salleh, \& Ahmad, 2015; Salehi, Bayaz \& Naemi, 2018). Furthermore, it is confirmed that timely audit reports are associated with numerous advantages. For example, lower information asymmetry between shareholders and company's management, convenient content of the audit report and reduce uncertainty in investment decisions (Mande \& Son, 2011; Salehi et al., 2018). Audit report timeliness is considered to be an important measure of the quality, reliability and relevance of accounting information (Krishnan \& Yang, 2009; 
Abernathy et al., 2017). Besides that, timeliness of audit report also reflects auditor's efficiency (Abernathy et al., 2017). It is asserted that disclosure on time is an indication that, higher efficient auditors carry out timely audits (Habib, 2015). Increasing audit time leads to adverse outcomes, for instance, auditor resignations and restatement of financial statement (Mande \& Son 2011), which provides insights about the lower audit quality.

The issue of timely provision of audited financial report gained more importance in emerging countries compared to developed countries (Abernathy et al., 2017). In these world settings, such as Oman and other Gulf Corporation Countries (GCC), the regulatory authorities are ineffective (Saidi \& Kumar, 2008; Amrah, Hashima \& Ariff, 2015), and news outlets and intermediaries of financial are underdeveloped compared to the developed countries (Khasharmeh \& Aljifri, 2010; Baatwah et al., 2015). To support this argument, Al-Ajmi (2009) and Khasharmeh and Aljifri (2010) asserted that audited financial information provided in annual reports is the only reliable source of information available to the investors and users in the GCC markets to set their investment decisions. Eventhough, annual reports in emerging countries as the GCC are untimely disclosure (Afify, 2009; Baatwah et al., 2015). For this reason, investigating the factors impacting audit report timeliness is a critical issue in Omani setting.

In the aftermath of Enron bankruptcy in 2001 and collapse of Arthur Andersen, the regulators have expressed concern over these collapses, and interest to the quality of audit and accounting profession increased (Francis, 2004). These led to the establishment of the Public Company Accounting Oversight Board (PCAOB), which is responsible of organizing and supervising the audit profession in the US (Francis, 2004). In 2004, the Standing Advisory Group (SAG) of PCAOB improved the monitor systems ingredients of audit quality. The SAG advocated that human element (audit team) within the audit firms is an essential determinant for audit quality (Cheng, Liu \& Chien, 2009). Furthermore, recent studies have highlighted that, audit partner is a basic determinant of audit quality (e.g. Francis, 2011; Gul, Wu \& Yang, 2013; Knechel, Vanstraelen \& Zerni, 2015). They reported that, audit partner personal characteristics have a strong effect in determining the quality of audit outcomes more than the audit firm characteristics.

Previous literature indicates that, the characteristics of audit partner related to skills, experience, knowledge, and educational attainment are the primary drivers to develop the audit quality, and enhance audit outcomes (Cheng, Liu \& Chien, 2009; Knechel, Krishnan, Pevzner, Shefchik \& Velury, 2013). Likewise, Sharma, Tanyi and Litt (2017) reported that audit partner with knowledge and experience reduces the timeliness of audit report. Although the importance of engagement audit partner characteristics on audit quality and its outcomes, however, with the best of the author's knowledge, there is no evidence that examined the impact of individual audit partner characteristics such as education and experience on audit report timeliness as auditing outputs, but with respect to the characteristic of partner tenure, two studies have recently been conducted on audit partner's tenure, by Sharma et al. (2017) in the US and by Wan Hussin, Bamahros and Shukeri (2018) in Malaysia. They argued that, the evidence on the influence of partner tenure over audit timeliness still represents a notable lack and needs more research. Thus, this study fills this gap by by providing the first 
conceptual framework of the influence of audit partner characteristics, namely experience, education and tenure on audit report timeliness in a unique setting within the Middle East and North Africa (MENA) such as Oman.

\section{Hypotheses Development}

Audit quality is the combined probability that the auditor discovers the breaches and misconduct in financial statements and discloses them to the shareholders and users of financial statements (DeAngelo, 1981; Knechel et al., 2012). Accordingly, the reliability and relevance of such statements can be accomplished if these statements are certified by high-quality auditors (Francis, 2004, Al-Ajmi, 2009). Previous scholars have determined audit quality as a critical stipulation to safeguard the quality of financial statements (Francis, 2004; Gul, Fung \& Jaggi, 2009). Audit quality reduces the agency costs. Agency theory posits that external auditor quality is considered to be a significant instrument to corporate monitoring and mitigating agency problems that arise from information asymmetry between the principle and agent (Jensen \& Meckling, 1976; Al-Ajmi, 2008), and conflict of interests among the principal's and agent's aims (Jensen \& Meckling, 1976), as well as, confirmed the fairness of financial reports (Cohen, Krishnamoorthy \& Wright, 2008). This assignment can be performed through audit partner, who has an adequate level of experience and knowledge to promote audit outcomes (Cahan \& Sun, 2015).

The Omani regulatory bodies highlight the quality of financial reporting as a top priority. All listed firms should apply the International Financial Report Standards (IFRS) when preparing the quarterly and annual reports and publish them. They are further requested to employ external auditors among those recognized by the Capital Market Authority (CMA). Additionally, external auditors are required to implement the International Auditing Standards (IAS), and the auditors are banned from provision non-audit services and any other types of services to maintain the auditors' independence, as well as, the auditors' rotation every four consecutive years (CMA, 2002). Furthermore, the amended Commercial Companies Law No 99 for 2005 in Oman stipulate that all listed companies in the stock market shall disclose the audited annual reports within two months. This specific deadline considers a significant shorter compared with some developed countries (e.g. UK and Australia) and developing countries (e.g. Malaysia, China and Egypt) (Knechel, Sharma \& Sharma, 2012; Basuony et al., 2016). Nevertheless, it is argued that imposing 60 days as a filing deadline would impose difficulties for firms and their auditors to adhere to such demand, and increase the pressure on auditor for completing audit work on time (Glover, Hansen \& Seidel., 2018). Thus, studying audit partner characteristics in setting with such demand will show to what extent these characteristics are significant in limiting this concern.

However, there are some situations which may hinder the effective application of Omani regulations. The weakness of the legal environment to protect the rights of shareholders and ineffectiveness of corporate governance mechanisms both contribute to more conflict of interests among controlling and non-controlling shareholders (Saidi \& Kumar, 2008; Amrah et al., 2015). Additionally, high level of ownership concentration particularly by family ownership creates the agency conflicts in Omani companies among the majority and minority 
shareholders (Amrah et al., 2015). Therefore, listed Omani companies are requested to have high audit quality as an external monitoring mechanism effective to safeguard the high quality of financial reports and ensure the rights of shareholders. In case of this study, the characteristics of audit partner quality (e.g. education, experience and tenure), which explains the skills and knowledge of auditor partner are used to examine their influence in mitigating the asymmetry of information and agency conflict among managers and owners, and between majority and minority shareholders, that is through the ability of these characteristics of audit partner in improving the timeliness of audit report.

\subsection{Audit Partner Quality}

An increasing number of recent auditing literature has switched the research concentration from the level of audit firm to the level of individual audit partner to better understand the behavior of auditors and audit quality (e.g. Chenget al., 2009; Gul et al., 2013; Cahan \& Sun, 2015; Li, Qi, Tian, \& Zhang., 2016). Recognizing the rising significance to study the auditing outcomes at the level of engagement audit partner, DeFond and Zhang (2014) recommended audit researchers to employ the characteristics of audit partner besides audit firm characteristics and auditor office in order to capture audit competency. As confirmed by Gul et al. (2013) and Cameran, Ditillo and Pettinicchio (2017), there is much variation in the quality of audit partners that greatly affect auditing outcomes compared to audit firms' quality even inside auditing firms with a better reputation. According to the framework of the relationship among the auditors' characteristics and audit outcomes proposed by the U.K. Financial Reporting Council (2008), personal qualities, knowledge, expertise, and skills for individual audit partner and staff are the most important drivers of audit quality and strengthen the audit reports (Knechel et al., 2013).

Using the data of partner level, recent empirical studies found that audit outcomes differ across partners, indicating that the incentives and expertise of partners vary from those of the offices and the firms (Carey \& Simnett, 2006; Gul et al., 2013; Cameran et al., 2017). Additionally, other scholars showed that, education and experience of the audit partner contribute mainly in audit failure and success ( $\mathrm{Li}$ et al., 2016). Nevertheless, majority of research concentrated on the audit quality characteristics at the audit firm level and neglects the characteristics of audit quality at the individual audit partner level (e.g. Al-Ajmi, 2008; Abidin \& Ahmad-Zaluki, 2012; Dao \& Pham, 2014). Therefore, most scholars made recommendations on the need to perform studies on the relationship among individual audit partner characteristics and audit reporting quality (DeFond \& Zhang, 2014; Knechel et al., 2015; Goodwin \& Wu, 2016). Accordingly, this study enriches and extends the audit report timeliness research by including the characteristics of audit quality at the level of audit partner.

\subsubsection{Partner Education}

Stiglitz (1975) suggested that education is an effective mechanism to decrease the gap between factual productivity and predicted productivity. For instance, the academic education of auditor mitigates the expectations gap among auditors and users of accounting information about the information contained in the audit report (Monroe \& Woodliff, 1993). As reported by Cheng et al (2009), educational attainment for human capital in audit firms is associated 
with audit quality. Education simplifies the acquisition of demanded knowledge for individuals, which enable auditors to issue varying audit judgments. Furthermore, Gul et al. (2013) and Li et al. (2016) point out that, the academic education, particularly in major of accounting of audit partners, strengthens their performance and professional abilities to gain better knowledge and experience for supporting the quality of audit outcomes.

Empirical research has found that audit performance has a positive relationship with the education level of auditors (Bröcheler, Maijoor and Witteloostuijn, 2004). Likewise, Cheng et al. (2009) found a positive and significant relationship on the association of educational attainment for auditor and auditor quality. Li et al. (2016) showed strong relationship between auditors with low education level and are not majored in accounting and lower audit quality. Therefore, based on the evidence above, this paper foresees that audit partners with an academic education degree specializing in accounting or auditing are more competent to enhance the audit outcomes, and it can be proposed that audit partner education is negatively related to audit report timeliness.

\subsubsection{Partner Experience}

The second important dimension for audit quality is auditor's experience. According to Bröcheler et al. (2004), experience builds the knowledge and skills of auditors and is an indicator of their efficiency. The highly experienced auditor is more conversant with strict standards of firm and this minimizes the influences of time pressure (Cianci \& Bierstaker, 2009), thus enabling the auditor to control the audit risk factors accurately and quickly when planning the procedures of audit (Cianci \& Bierstaker, 2009), thereby, lowering the allocated time of audit executing and improve the timely audit report. Lee and Jahng (2008) assert that, audit partners with experience or specialization have the ability to do audit work faster and issue the audit report in a shorter time. Prior empirical studies such as Cheng et al. (2009) showed a significant positive relationship between an individual auditor's experience and audit quality. Gul et al. (2013) and Cahan and Sun (2015) found that audit partner experience reduces earnings management and enhance audit quality. In view of the above scenario, partner experience supports audit quality and its outcomes. As audit timeliness is deemed a measure of audit quality (Glover et al, 2018). This study predicts that audit partner experience is negatively related to audit report timeliness.

\subsubsection{Partner Tenure}

The discussions on the cons and pros of partner tenure have attracted the attention of both practitioners of audit and academic. Some researchers argue that, as the auditors' competence increase during tenure, a coercive change of partner may negatively impact on auditing outcomes by the loss of partner who has acquired more expertise and client-specific knowledge over a long period of engagement (Bedard \& Johnstone, 2010; Cahan \& Sun, 2015; Sharma et al., 2017). On another perspective, change of audit partner could bring a fresh point of views and promote the audit partner independence and its objectivity to report the financial statements with high quality (Carey \& Simnett, 2006; Daugherty, Dickins, Hatfield \& Higgs, 2012). However, some audit practitioners and academics opposed the rules of new partner rotation and argue that, further to deteriorating the audit quality, it will have 
greater influence on costs of audit, and loss of expertise and industry-specific knowledge about the client which occur as a result of partners' rotation (George, 2004; Daugherty et al. 2012).

One of the earliest studies was conducted by Carey and Simnett (2006) found that, long partner tenure is related to fewer tendencies to receive a modified opinion of growing concern, suggesting the close relationship with a client negatively effect on audit quality and decisions of partner. Bedard and Johnstone (2010) showed that shorter partner tenure is positively related to planned audit task hours and negatively with the rates of planned realization. Moreover, there is a deficit in research that addresses partner tenure with audit timelines. For example, Sharma et al. (2017) and Wan Hussin et al. (2018) found that, long-term partner tenure leads to shortened audit report time. Based on the above discussion, this study postulates that audit partner tenure is negatively related to audit report timeliness.

\section{Conceptual Framework}

Figurelbelow shows the conceptual framework of the study on the relationship between the characteristics of audit partner quality namely, education, experience and tenure as independent variables and audit report timeliness as the dependent variable. This framework tries to narrow the gap in the audit timeliness literature by focusing on the audit quality at the level of partners rather than audit firm level, to conduct a thorough and insightful investigation on the efficiency and quality of the audit as recently recommended by some scholars (e.g. Goodwin \& Wu, 2016; Wan Hussin et al., 2018).

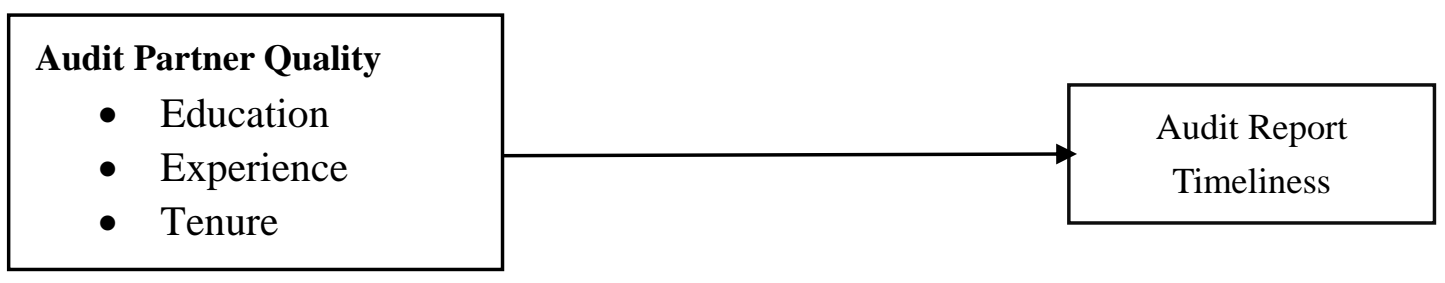

Figure 1. Conceptual framework

\section{Conclusion and Future Research}

Given the importance of individual audit partner in affecting audit quality and the quality of financial reporting outcomes, several recent studies have switched their interested area to focus on the characteristics of individual audit partner instead of audit firm characteristics in developed and developing countries, for instance, Cheng et al. (2009) in Taiwan, Gul et al. (2013) in China, Goodwin and Wu (2016) in Australia, and Cameran et al. (2017) in Italy and so on. To the best of the researcher's knowledge, this is the first study conducted in the MENA, particularly in Oman, which examines similar issue. This paper adds to this series of studies by proposing a conceptual framework which explains how the characteristics of the individual audit partner (e.g. education, experience, and tenure) affect the timing of audit report as one of the important measures of audit quality. This study is considered as a transit gate for future studies in the field of audit timeliness and the development of new knowledge on audit quality at the level of individual partner and the extent of its impact on audit reports 
timeliness in the different settings. It is expected that, if future empirical studies adopt this conceptual framework in future especially in Oman, it will provide alert signs about the efficiency and quality of audit services market and its impact on the timing and quality of accounting information provided to investors and various shareholders. Thereby, giving important indicators for regulatory bodies that organize the auditing and accounting profession to evaluate audit quality in listed firms, as well as providing a picture about the delay level of audit timeliness in MENA states in general and in Oman in particular.

\section{References}

Abernathy, J. L., Barnes, M., Stefaniak, C., \& Weisbarth, A. (2017). An international perspective on audit report lag: A synthesis of the literature and opportunities for future research. International Journal of Auditing, 21(1), 100-127.

Abidin, S., \& Ahmad-Zaluki, N. A. (2012). Auditor industry specialism and reporting timeliness. Procedia- Social and Behavioral Sciences, 65, 873-878.

Afify, H. A. E. (2009). Determinants of audit report lag: Does implementing corporate governance have any impact? Empirical evidence from Egypt. Journal of Applied Accounting Research, 10(1), 56-86.

Al-Ajmi, J. (2008). Audit and reporting delays: Evidence from an emerging market. Advances in Accounting, 24(2), 217-226.

Al-Ajmi, J. (2009). Audit firm, corporate governance, and audit quality: Evidence from Bahrain. Advances in Accounting, 25(1), 64-74.

Amrah, M. R., Hashima, H. A., \& Ariff, A. M. (2015). The moderating effect of family control on the relationship between board of directors effectiveness and cost of debt: Evidence from Oman. International Journal of Economics, Management and Accounting, 23(2), 217.

Baatwah, S. R., Salleh, Z., \& Ahmad, N. (2015). Corporate governance mechanisms and audit report timeliness: empirical evidence from Oman. International Journal of Accounting, Auditing and Performance Evaluation, 11(3-4), 312-337.

Basuony, M. A., Mohamed, E. K., Hussain, M. M., \& Marie, O. K. (2016). Board characteristics, ownership structure and audit report lag in the Middle East. International Journal of Corporate Governance, 7(2), 180-205.

Bedard, J. C., \& Johnstone, K. M. (2010). Audit partner tenure and audit planning and pricing. Auditing: A Journal of Practice \& Theory, 29(2), 45-70.

Blankley, A. I., Hurtt, D. N., \& MacGregor, J. E. (2014). The relationship between audit report lags and future restatements. Auditing: A Journal of Practice \& Theory, 33(2), 27-57.

Bröcheler, V., Maijoor, S., \& van Witteloostuijn, A. (2004). Auditor human capital and audit firm survival. The Dutch audit industry in 1930-1992. Accounting, Organizations and Society, 29(7), 627-646. 


\section{$\triangle 1$ Macrothink}

International Journal of Accounting and Financial Reporting

ISSN 2162-3082 2019, Vol. 9, No. 1

Cahan, S. F., \& Sun, J. (2015). The effect of audit experience on audit fees and audit quality. Journal of Accounting, Auditing \& Finance, 30(1), 78-100.

Cameran, M., Ditillo, A., \& Pettinicchio, A. (2017). Audit team attributes matter: How diversity affects audit quality. European Accounting Review, 8180, 1-27.

Capital Market Authority. (2002). Code of corporate governance for Muscat Security Market Listed Copanies. Sultanate of Oman.

Carey, P., \& Simnett, R. (2006). Audit partner tenure and audit quality. The Accounting Review, 81(3), 653-676.

Cheng, Y. S., Liu, Y. P., \& Chien, C. Y. (2009). The association between auditor quality and human capital. Managerial Auditing Journal, 24(6), 523-541.

Cianci, A. M., \& Bierstaker, J. (2009). Auditors' efficiency motivated evaluation. Advances in Accounting, 25(1), 20-27.

Cohen, J. R., Krishnamoorthy, G., \& Wright, A. M. (2008). Form versus substance: The implications for auditing practice and research of alternative perspectives on corporate governance. Auditing: A Journal of Practice \& Theory, 27(2), 181-198.

Commercial Company Law. (1974). Amendment article No. 105, 2005, Oman. Retrieved from https://www.moci.gov.om/.../04_Sj9CPykssy0xPLMnMz0vMAfGjz

Dao, M., \& Pham, T. (2014). Audit tenure, auditor specialization and audit report lag. Managerial Auditing Journal, 29(6), 490-512.

Daugherty, B. E., Dickins, D., Hatfield, R. C., \& Higgs, J. L. (2012). An examination of partner perceptions of partner rotation: Direct and indirect consequences to audit quality. Auditing: A Journal of Practice \& Theory, 31(1), 97-114.

DeAngelo, L. E. (1981). Auditor size and audit quality. Journal of Accounting and Economics, 3(3), 183-199.

DeFond, M. L., \& Francis, J. R. (2005). Audit research after Sarbanes-Oxley. Auditing: A Journal of Practice \& Theory, 24(1), 5-30.

DeFond, M., \& Zhang, J. (2014). A review of archival auditing research. Journal of Accounting and Economics, 58(2), 275-326.

Dry, E. K. (2003). Corporate Governance in the Sultanate of Oman. Richmond Journal of Global Law \& Business, 3(1), 45-82.

Financial Accounting Standards Board (FASB). (2010). Conceptual framework for financial reporting. Statement of Financial Accounting Concepts No. 8. Retrieved from https://www.fasb.org/resources/ccurl/515/412/Concepts\%20Statement\%20No\%208.pdf

Financial Reporting Council. (2008). The audit quality framework by the UK. London. Retrieved from 


\section{MlMacrothink}

International Journal of Accounting and Financial Reporting

ISSN 2162-3082

2019, Vol. 9, No. 1

https://frc.org.uk/getattachment/46582304-32b1-43bb-b614-90318b295f28/The-Audit-Qualit y-Framework-Feb-2008.pdf

Fodio, M. I., Ibikunle, J., \& Oba, V. C. (2013). Corporate governance mechanisms and reported earnings quality in listed Nigerian insurance firms. International Journal of Finance and Accounting, 2(5), 279-286.

Francis, J. R. (2004). What do we know about audit quality?. The British Accounting Review, $36(4), 345-368$.

Francis, J. R. (2011). A framework for understanding and researching audit quality. Auditing: A Journal of Practice \& Theory, 30(2), 125-152.

Francis, J. R., \& Yu, M. D. (2009). Big 4 office size and audit quality. The Accounting Review, 84(5), 1521-1552.

George, N. (2004). Auditor rotation and the quality of audits. The CPA Journal, 74(12), 22-26.

Givoly, D., \& Palmon, D. (1982). Timeliness of annual earnings announcements: Some empirical evidence. Accounting Review, 57(3), 486-508.

Glover, S., Hansen, J., \& Seidel, T. (2018). The effect of regulatory and standard setting changes on the information conveyed by the audit report date about audit completeness. Retrieved from https://ssrn.com/abstract=2561713

Goodwin, J., \& Wu, D. (2016). What is the relationship between audit partner busyness and audit quality?. Contemporary Accounting Research, 33(1), 341-377.

Gul, F. A., Fung, S. Y. K., \& Jaggi, B. (2009). Earnings quality: Some evidence on the role of auditor tenure and auditors' industry expertise. Journal of Accounting and Economics, 47(3), 265-287.

Gul, F. A., Wu, D., \& Yang, Z. (2013). Do individual auditors affect audit quality? Evidence from archival data. The Accounting Review, 88(6), 1993-2023.

Habib, A. (2015). The New Chinese Accounting Standards and Audit Report Lag. International Journal of Auditing, 19(1), 1-14.

Jensen, M. C., \& Meckling, W. H. (1976). Theory of the firm: Managerial behavior, agency costs and ownership structure. Journal of Financial Economics, 3(4), 305-360.

Khasharmeh, H. A., \& Aljifri, K. (2010). The timeliness of annual reports in Bahrain and the United Arab Emirates: An empirical comparative study. The International Journal of Business and Finance Research, 4(1), 51-71.

Knechel, R., Sharma, D. S., \& Sharma, V. D. (2012). Non-audit services and knowledge spillovers: Evidence from New Zealand. Journal of Business Finance \& Accounting, 39(1-2), 60-81. 


\section{Mll Macrothink}

International Journal of Accounting and Financial Reporting

ISSN 2162-3082 2019, Vol. 9, No. 1

Knechel, W. R., \& Sharma, D. S. (2012). Auditor-provided nonaudit services and audit effectiveness and efficiency: Evidence from pre-and post-SOX audit report lags. Auditing: A Journal of Practice \& Theory, 31(4), 85-114.

Knechel, W. R., Krishnan, G. V., Pevzner, M., Shefchik, L. B., \& Velury, U. K. (2013). Audit quality: Insights from the academic literature. Auditing: A Journal of Practice \& Theory, 32(1), 385-421.

Knechel, W. R., Vanstraelen, A., \& Zerni, M. (2015). Does the identity of engagement partners matter? An analysis of audit partner reporting decisions. Contemporary Accounting Research, 32(4), 1443-1478.

Krishnan, J., \& Yang, J. S. (2009). Recent trends in audit report and earnings announcement lags. Accounting Horizons, 23(3), 265-288

Lee, H., \& Jahng, G. (2008). Determinants of audit report lag: Evidence from Korea-an examination of auditor-related factors. Journal of Applied Business Research, 24(2), 27.

Leventis, S., \& Caramanis, C. (2005). Determinants of audit time as a proxy of audit quality. Managerial Auditing Journal, 20(5), 460-478.

Li, L., Qi, B., Tian, G., \& Zhang, G. (2016). The contagion effect of low-quality audits at the level of individual auditors. Accounting Review, 92(1), 137-163.

Mande, V., \& Son, M. (2011). Do audit delays affect client retention?. Managerial Auditing Journal, 26(1), 32-50

Monroe, G. S., \& Woodliff, D. R. (1993). The effect of education on the audit expectation gap. Accounting \& Finance, 33(1), 61-78.

Oussii, A. A., \& Boulila Taktak, N. (2018). Audit report timeliness: Does internal audit function coordination with external auditors matter? Empirical evidence from Tunisia. EuroMed Journal of Business, 13(1), 60-74.

Owusu-Ansah, S. (2000). Timeliness of corporate financial reporting in emerging capital markets: Empirical evidence from the Zimbabwe Stock Exchange. Accounting and Business Research, 30(3), 241-254.

Ram, B. R., \& Hassan, A. N. (2017). Audit Quality and Audit Report Lag in Malaysia. Imperial Journal of Interdisciplinary Research, 3(10), 624-630.

Saidi, N., \& Kumar, R. (2008). Corporate governance in the GCC. Hawkamah Institute for Corporate Governance Paper, UAE. Retrieved from nassersaidi.com/wp.../CORPORATE-GOVERNANCE-IN-THE-GCC-APR-2007.pdf

Salehi, M., Lari Dasht Bayaz, M., \& Naemi, M. (2018). The effect of CEO tenure and specialization on timely audit reports of Iranian listed companies. Management Decision, 56(2), 311-328. 


\section{Macrothink}

International Journal of Accounting and Financial Reporting ISSN 2162-3082 2019, Vol. 9, No. 1

Sharma, D. S., Tanyi, P. N., \& Litt, B. A. (2016). Costs of mandatory periodic audit partner rotation: Evidence from audit fees and audit timeliness. Auditing: A Journal of Practice \& Theory, 36(1), 129-149.

Stiglitz, J. E. (1975). The theory of "screening" education, and the distribution of income. The American Economic Review, 65(3), 283-300.

Swanson, Z., \& Zhang, Y. (2018). Do covenant violations affect audit report timeliness?. International Journal of Accounting, Auditing and Performance Evaluation, 14(1), 1-23.

Wan Hussin, W. N., Bamahros, H. M., \& Shukeri, S. N. (2018). Lead engagement partner workload, partner-client tenure and audit reporting lag: Evidence from Malaysia. Managerial Auditing Journal, 33(3), 246-266.

\section{Copyright Disclaimer}

Copyright for this article is retained by the author(s), with first publication rights granted to the journal.

This is an open-access article distributed under the terms and conditions of the Creative Commons Attribution license (http://creativecommons.org/licenses/by/4.0/) 